\title{
Küresel Yönetişim Ekseninde Stratejik Planlarda Koordinasyonun Önemi
}

\author{
Ömer Faruk GENÇKAYA* \\ Hakan Gökhan GÜNDOĞDU**
}

\section{Öz}

Küresel yönetişimde devletler arası-hükümetler arası ortak hedeflerin yerine getirilmesinde koordinasyonun sağlanması, kamu yönetiminde değişimin başlıca göstergelerindendir. Küresel yönetişimde yaşanan gelişmeler yerelden küresele doğru artan işbirliği ve koordinasyonu zorunlu kılmıştır. Bu çalışma, kamu politikalarında koordinasyonun sağlanmasına yönelik adımları ele almaktadır. Bubağlamda, koordinasyonun avantajlarındanvekoordinasyonsuzluğun dezavantajlarından bahsedilmekte ve kamu politikalarında koordinasyonun etkinliğini ölçecek kriterler sunulmaktadır. Çalışma iki ana bölümden oluşmaktadır. İlk olarak, Türk kamu yönetiminde kamu politikalarının koordinasyonunda stratejik planlamanın yeri ve önemi tartışılmaktadır. İkinci olarak, Türk kamu yönetiminde stratejik planlama ve koordinasyonla ilgili Avrupa Birliği Komisyonu’nun "2015 İlerleme Raporu” ve Kalkınma Bakanlığı’nın hazırlamış olduğu “Stratejik Yönetimde Kapasite Geliştirme Teknik Destek Projesi Revize Edilmiş Taslak Boşluk Değerlendirme Raporu” 1şığında irdelenmektedir. Son olarak, Türk kamu yönetiminde koordinasyonun etkinliğinin değerlendirilmesi ve yapılması gereken iyileştirmeler tartışılmaktadır.

Anahtar kelimeler: Küresel Yönetişim, Kamu Yönetiminde Etkinlik, Koordinasyon, Stratejik Planlama, 5018 Sayılı Kanun.

\section{The Importance of Coordination in the Strategic Plans in the Context of Global Governance}

\begin{abstract}
In global governance, ensuring coordination in the fulfillment of common intergovernmental and intergovernmental objectives is a major indicator of change in public administration. Developments in global governance have inevitably necessitated increased cooperation and coordination from local to global. This study addresses the steps to ensure coordination in public policies. In this context, the advantages of coordination and disadvantages of incoordination are discussed, and the criteria to measure the effectiveness of coordination in public policies are presented.
\end{abstract}

Prof. Dr., Marmara Üniversitesi, SBF, Fr. Siyaset Bilimi ve Kamu Yönetimi Bölümü, faruk.genckaya@marmara.edu.tr

** Arş. Gör., Marmara Üniversitesi, Sosyal Bilimler Enstitüsü, hakan.gundogdu@marmara.edu.tr 
The study consists of two main parts. First, the place and the importance of strategic planning in the coordination of public policies in Turkish public administration are discussed. Secondly, strategic planning and coordination in Turkish public administration is discussed in the light of the EU Commission's "2015 Progress Report" and the "Revised Draft Gap Analysis Report on Capacity Building in Strategic Management", which is prepared by the Ministry of Development. Finally, the evaluation of the effectiveness of coordination in Turkish public administration and the necessary improvements are discussed.

Keywords: Global Governance, Effectiveness in Public Management, Coordination, Strategic Planning, The Law No. 5018.

\section{Giriş}

Soğuk savaş döneminin sona ermesiyle birlikte; iki kutuplu dünya düzeninden, Birleşmiş Milletler'in daha etkin olacağı bir yapıya geçilmesi beklenmiştir (Latif, 1999). Küreselleşmenin yaygınlaşması, dünya ekonomisinde yaşanan hızlı büyüme ve bu büyümenin etkilediği varsayılan kurumsal yapılarla birlikte; ulus devletlerin birbirleriyle olan ilişkileri küresel düzeyde artı̧̧ göstermektedir. Bu bağlamda, küresel yönetişim, uluslararası ekonomi politikalarında kendini göstermiştir (Volz, 2011). Özellikle, İkinci Dünya Savaşı’ndan sonra, Uluslararası Para Fonu, Dünya Bankası ve Dünya Ticaret Örgütü ile birlikte uluslararası bir ekonomik yapının oluşturulması amaçlanmıştır. Daha sonra neo-liberalizm ve küreselleşmenin etkisi ile birlikte küresel yönetişim geniş kapsamlı, etkin ve karmaşı özellikleri olan küresel düzeyde karşlıklı karar verme süreçlerini olușturmuștur (Heywood, 2014: 537-538).

Kamu yönetimindeki değişim sürecinin, özellikle geçen yüzyılın sonunda neo-liberal politikaların etkisi ve devletin etki alanının küçültülmesi ile birlikte daha etkin hale geleceği tartışmaları yapılmaktadır. Böylece, özel sektörde var olan verimlilik ve etkililiğin esas alındığı liberal piyasa temelli bir kamu yönetimine doğru gelişme yaşanacağı öngörülmektedir. Kamu yönetimindeki reform anlayışı, kamu yönetiminde yaşanan değişim ve dönüşüm süreci ile devlet, özel sektör ve sivil toplum kuruluşlarının (devlet dışı kuruluşlar) eklemlendiği bir yapıyı oluşturmaktadır. Kamu yönetiminde katılımclık, hesap verebilirlik ve açıklık gibi ilkelerin temel alındığı kamu politikalarının oluşturulmasında, merkezi bir yapının tek taraflılı̆̆ yerine, koordinasyon ve işbirliği temelli ve çok düzlemli/aktörlü yönetişimsel süreçler ön plana çıkmaktadır (Kavruk, 2005: 367).

$\mathrm{Bu}$ çalı̧̧mada, küresel yönetişim bağlamında gelişen iş birliği ve koordinasyon gereksiniminin yanında, kamu politikalarında koordinasyonun gerekliliğinin nedenleri açılanmaktadır. Ayrıca, çalışmada kamu kurumlarındaki politika amaçlarının belirlenmesinde ve koordinasyon sağlanmasında rol oynayan stratejik planların önemi üzerinde durulmaktadır (Matei ve Dogaru, 2012). Son olarak, Türk kamu yönetiminde stratejik planlama ve koordinasyon eksikliği üzerine yapılan tespitlerin ortaya çıkartılması ve koordinasyonun sağlanması temelinde değerlendirmelerde bulunulmaktadır. 


\section{Küresel Yönetişim ve Koordinasyon İlişkisi}

Küresel yönetişim, işbirliği yoluyla sorunları çözmeye yardımcı olan hükümetler arası ve hükümet-dışı kuruşların yanında, resmi ve resmi olmayan oluşumları da içeren geniş kapsamlı bir karar verme sürecini ifade etmektedir (Boughton ve Bradford, 2007). Küresel yönetişim, esas olarak, ulus devletlerin, kendi çıkarları doğrultusunda merkezi bir politikanın yönlendirmediği bir ortamda, gönüllü bir şekilde ortak ve karşılıklı çıkar temelinde küresel politikalara uymalarını anlatır. Küresel yönetişimin ortaya çıkmasının başka bir sebebi, ulus devletlerin politikalarında ortaya çıkan sorunları, diğer ulus devletlerle birlikte çözebilecekleri bir yapıya duyulan gereksinimdir. Bu bağlamda, küresel yönetişimin çok merkezlilik (dinamik ve kapsamlı karar verme mekanizmaları), hükümetler arası nitelik (ikili anlaşmalar, ittifaklar), farklı aktörlerin sürece katılması (devletler, uluslararası örgütler, çok uluslu şirketler, küresel sivil toplum örgütleri gibi) çok düzeyli süreçler (yerelden küresele doğru yaşanan karşılıklı ilişkiler) ve resmiyetten arınma gibi temel özellikleri bulunmaktadır (Weiss, 2013; Heywood, 2014: 538-542).

Küreselyönetişim anlayışına göre, uluslararası sorunlarda ulusal çıkarların tanımlanması, koordine edilmesi ve uyumlu hale getirilmesi uluslararası platformlar aracılığıyla gerçekleşebilmektedir. $\mathrm{Bu}$ uluslararası platformlar, ulus devletlerin stratejik amaç ve önceliklerini ifade edebilecekleri ve karşılıklı çıkara dayalı bir yapı oluşturması nedeniyle, küresel yönetişim ve koordinasyon yönünden bir fırsat oluşturmaktadır. Küresel politika ortamında ulusal ve yerel çıkarları uzlaştırmak amacıyla, ulusal hükümetler iletişim ve istişare yoluyla diğer ulusal hükümetlerle ya da ulus üstü kurumlarla işbirliğini ve koordinasyonu geliştirmenin yollarını aramaktadır. Örneğin, Avrupa Birliği bölgesel grupların gelişmesine öncülük ederken, Dünya Ticaret Örgütü gibi uluslararası kuruluşlarda küresel ticaret politikalarında işbirliğine yardımcı olmaktadırlar. Bu bağlamda, küresel yönetişim, uluslararası veya çok taraflı anlaşmalar yoluyla uluslararası bir güç dengesi oluşturmaktadır (OECD, 1996: 9-12).

OECD ülkelerinin birçoğu, ulusal politika yapımı süreçleri, demokrasi, şeffaflık, açıklık ve hesap verebilirlik gibi yönetişim ilkelerini geliştirmek için son zamanlarda önemli adımlar atmıştır (OECD, 2003). Ulusal düzeyde atılan bu adımlara rağmen küresel düzeyde yönetişime dair adımlar ağır işlemektedir. Buna karşın Birleşmiş Milletler, Dünya Ticaret Örgütü, Avrupa Birliği, Uluslararası Para Fonu ve Dünya Bankası, OECD gibi uluslararası kuruluşların ilgili politika alanlarında koordinasyon kurulları bulunmaktadır. Öte yandan, demokrasi, şeffaflık, açılklk ve hesap verebilirlik gibi yönetişim ilkelerinin küresel yönetişim yapılarının gelişmesinde önemli rolleri bulunmaktadır (OECD, 1996: 14-15). Özellikle, Avrupa Birliği küresel yönetişim ve çok düzlemli yönetişime örnek olarak gösterilmektedir. Avrupa Birliği ulus üstü bir yapı olarak Avrupa Parlamentosu, Komisyon, Konsey ve (ulusal parlamentolar dahil) üye ulusal yönetimler arasındaki görece roller, sorumluluklar ve ilişkiler çok düzlemli yönetişime örnek teşkil etmektedir (Okçu, 2005). 


\section{Kamu Politikalarında Koordinasyonun Gerekliliği}

Yeni Kamu Yönetimi yaklaşımı, esas olarak "bölünme” (fragmentation) ve stratejisi üzerine kurulmuştur (Pollitt ve Bouckaert, 2004). Politika yapma ve yönetim süreçleri birbirinden ayrıştırılarak ayrılmıştır. Dikey uzmanlaşma sonucunda, kamu yönetimi üzerindeki siyasi etkinin azaltılması hedeflenmiştir. Öte yandan, yatay uzmanlaşma nedeniyle, kapasite ve koordinasyon mekanizmalarında değişiklik gereksinimi ortaya çıkmıştır (Gregory, 2003). Bir yandan iç denetim mekanizmaları güçlenirken, öte yandan çeşitli araçlar ile gözetim ve denetim yapılması önem kazanmıştır (Pollitt vd. 1999).

Koordinasyon, ortak hedeflerin yerine getirilmesinde kurumlar-aktörler arasında organize bir şekilde hareket edilmesidir (Malone, 1988: 5). Bunun yanı sıra koordinasyon; etkinlikler ya da uygulamalar arasındaki bağımlılığın ve ilişkinin tutarlı bir şekilde yönetilmesidir. Koordinasyonun sağlanması sürecinde dayanışma ve işbirliği içerisinde olunması önemli bir yer tutmaktadır (Malone ve Crawston, 1994: 90). Koordinasyon bazı kurumsal yararlar sunmaktadır (State Services Commission, 2008: 10):

$>$ Kurumun gelişmesine ve sonuç odaklılığa katkı sağlamaktadır.

> Kurumun amaçlarının ve stratejilerinin başarılı olmasına yardımcı olmaktadır.

$>$ Kurum içi fayda maliyet yaklaşımı ve ölçek ekonomisini hayata geçirmektedir.

$>$ Kurumlar arası işbirliğinin sağlanmasına yol göstermektedir.

> Kurumun müşteri ve kalite odaklı çalışmasının önünü açmaktadır.

$>$ Kurum içi kararsızlık veya çatışma durumlarında çözüme yardım etmektedir.

Öte yandan, koordinasyonsuzluk, bazı olumsuzluklara ve maliyetlere yol açmaktadır (State Services Commission, 2008: 10):

$>$ Kurum içi kararsızlık durumlarına neden olmaktadır.

$>$ Kurumsal etkinliğin ve bunun etkisinin ölçülmesinde, karmaşık bir performans ölçüm sistemine neden olmaktadır.

> Kurumsal ortak çalışma düzenlemelerinin sürdürülmesine bağlı olarak, personelin zaman planlamasında doğrudan ve dolaylı maliyetlere yol açmaktadır.

Koordinasyonun kamu politikalarında gerçekleşmesi, bölgesel, ulusal ve yerel düzeydeki sektörler arasında işbirliği ve iletişimin daha fazla ön planda olmasını gerektirmektedir (Sumpor, 2006: 2). Kamu politikalarının koordinasyon temelinde gerçekleşip etkin bir kamu yönetimine geçilebilmesinin belli koşulları bulunmaktadır. Kamu politikalarında koordinasyonun sağlanmasını yönelik çalışmalarda, ulusal düzeyde koordinasyonun sağlanmasının uluslararası düzeyde etkin katılıma da yardımcı olacağı ifade edilmektedir. Kamu politikalarında koordinasyonun sağlanmasına yönelik aşağıda sıralanan adımlar temelde, ulusal düzeyde bakanlıklarda koordinasyonunun sağlanmasının koşullarının açıklanmasıdır. Buna göre, dokuz adımda kamu politikalarının koordinasyonu öngörülmektedir (Metcalfe, 1994; OECD, 1996: 8): 
İlk önce, her bakanının yetkili olduğu kamu politikası alanında özerk ve bağımsız hareket etmesi yani bakanlıkların bağımsız bir şekilde-dayatma olmaksızın karar alabilmeleri gerekmektedir.

İkinci olarak, diğer bakanlıklarla bilgi alışverişi içerisinde-iletişim halinde olma, yani bakanlık ve diğer bakanlıklarında ilgi alanına giren ve onları etki eden konularda bilgi alışverişi içerisinde olmaları önem teşkil etmektedir. Bu bağlamda, koordinasyonun sağlanması için bakanlıkların kendi aralarında düzenli ve güvenilir iletişim kanallarına sahip olması gerekmektedir.

Üçüncü olarak, diğer bakanlıklarla danışma-istişare içerisinde olunan iki yönlü bir süreç söz konusudur. Bu adımda, kamu politikalarının belirlenmesi sürecinde bakanlıkların kendi içerisinde danışarak, birbirileriyle geri bildirim süreci içerisinde hareket etmeleri koordinasyonun sağlanmasında önem teşkil etmektedir.

Dördüncü olarak, bakanlıklar arasındaki görüş-fikir farklılıklarından kaçınmak gerekmektedir. Çünkü bakanlıkların görüş-fikir farklılıklarını müzakereye açması çelişkili durumlar ortaya çıkarabileceğinden, hükümetin yürütmede işleyişinin aksatabilmektedir. Bunun yerine, bakanlıkların uyumlu ve dengeli bir bakış açısıyla hareket etmeleri gerekmektedir.

Beşinci olarak, bakanlıkların kendi aralarında anlaşma ve uzlaşma zemini içerisinde hareket etmeleri gerekmektedir. Bakanlıkların ortak proje ve komisyonlar yoluyla birlikte çalışarak farklılıkları giderici ve karşılıklı bağımlılı̆̆ın gerçekleşeceği farz edilmektedir. Buna bağlı olarak, bakanlıklar arasında uyumlu ve koordineli işleyişin sağlanacağı öngörülmektedir.

Altıncı olarak, bakanlıklar arasında gerçekleşebilecek anlaşmazlıkların çözümünde tahkimhakem yoluna gidilmesidir. Bakanlıkların kendi aralarındaki anlaşmazlıklarının çözümünde ve koordinasyonun sağlanmasında hakemlik rolü genellikle hükümet tarafından yerine getirilir. Bu bağlamda, başbakan, bakanlıklar arasında gerçekleşebilecek anlaşmazlıkların çözümünde etkin rol alabilmektedir.

Yedinci olarak, bakanlıkların koordinasyonu için parametrelerin tanımlanması gereklidir. $\mathrm{Bu}$ parametreler, koordinasyonun sağlanmasında yerine getirilmesi gereken adımların belirlenmesinde önem teşkil etmektedir.

Sekizinci olarak, hükümetin önceliklerinin belirlenmesi gerekmektedir. Buna göre, hükümet merkezi politikanın ana hatlarını ortaya koyarak ve önceliklerini belirleyerek bakanlıklara yol ve yön tayin etmesi öngörülmektedir. Buna bağlı olarak, hükümet, kamu politikalarının koordinasyonunda yönlendirme işlevi görmektedir.

Son olarak, hükümetin kamu politikalarının koordinasyonunda genel bir stratejisinin olması gerekmektedir. Bu sayılan dokuz adıma ek ve özet olarak, kamu politikalarında etkin koordinasyonun sağlanması, planlamada bakanlıklar arasında işbirliğinin geliştiği bütüncül ve tutarlı yaklaşım içerisinde sorunların çözülmesini gerektirmektedir (Matei ve Dogaru, 2012: 1). Kamu politikalarında koordinasyon ve işbirliği sağlanmasında stratejik planlar araç olarak kullanılmaktadır. 


\section{Kamu Politikaları Koordinasyonunda Stratejik Planlamanın Önemi}

Stratejik planlama, bir kurumun ya da işletmenin ne yaptığını ve neden yaptığını sorgulayan, genel stratejik amaç ve hedefleri belirleyen, temel karar ve eylemleri üreterek kaynağının elde edilmesi ve dağıtımı için uygun politikalar seçen ve bu süreçte yol gösteren disiplinli bir çalışmadır (Steiss, 2003: 3; Bryson, 2004: 6). Stratejik planlama ile ilgili ilk uygulamalar, özel sektörde gelişim göstermiştir. 1960'ların sonu itibariyle detaylı planlamaya yönelik eleştirilere yanıt olarak, kamu kurum ve kuruluşlarında stratejik planlamaya yönelik adımlar atılmaya başlanmıştır (Steiss, 2003: 53). Stratejik planlama, iletişimi, katılımı, farklı değerleri ve çıkarları barındırmayı, uygun analitik kararlar vermeyi, hesap verebilirliği kolaylaştırmayı ve bu özelliklerin başarılı bir şekilde uygulamasını sağlamaktadır (Bryson, 2004: 6). Stratejik planlama temel olarak, en iyi sonuçları almak için etkili bilgi toplama, stratejik alternatif geliştirme, araştırma ve günümüzdeki kararların gelecekteki sonuçları üzerine vurgu yapmaktadır (Yılmaz, 2003: 71).

Stratejik planların kurumlarda ve işletmelerde çeşitli faydaları bulunmaktadır (Bryson, 2004: 11-12). İlk önce, stratejik planlar, özellikle, ilgili aktörler/paydaşlar arasında diyalog ve stratejik görüşme aracılığıyla stratejik düşünme ve öğrenmeyi arttırmaktadır. Stratejik planlar, kurumlar ya da işletmeler için en iyinin ne olduğunu düşünmeye ve bu doğrultuda kurumsal değişim süreçlerinin yönetilmesine yardımcı olmaktadır. İkinci olarak, stratejik planlama daha iyi karar verme sonucunu meydana getirmektedir. Kurumlar ya da işletmeler stratejik planlar aracılığıyla ve açık iletişim kanallarıyla tüm stratejik yönlerini tartışarak daha iyi karar verme sonucuna ulaşmaktadır. Üçüncü olarak, stratejik planlar aracılığıyla kurumsal etkinliğin arttırılması söz konusudur. Kurumsal etkinliğin arttırılması, kurumların ya da işletmelerin stratejik planlar aracılığıyla iyi yönetilmesidir. Kurumların ya da işletmelerin daha yenilikçi ve duyarlı, daha fazla etkiye sahip ve hesap verebilir, değișen koşullara daha hızlı ayak uyduran bir yapıya dönüşmesi de stratejik planların uygulanmasıyla gerçekleşmektedir. Dördüncü olarak, kurumsal etkinliğin ötesinde, stratejik planlama geniş toplumsal sistemlerin etkinliğini arttırabilmektedir. Eğitim, çevre, sağlık, işsizlik ve yoksulluk gibi toplumun tamamını ilgilendiren konularda da stratejik planlamanın önemi bulunmaktadır. Kamu kurum ve kuruluşları toplumun tamamını ilgilendiren bu geniş toplumsal sistemlerin sorunlarının çözümünde stratejik planlama kullanılmaktadırlar. Son olarak, stratejik planlamanın katılımcılara/bireylere doğrudan yararlar sağlar. Örneğin, stratejik planlamanın yapımında var olan ekip çalışması ve deneyimlerin arttırabilmesini sağlayan süreçler katılımcıların/bireylerin sorumluluklarını ve rollerini geliştirmelerine yardımcı olabilmektedir.

Stratejik planlama kavramı, kurumsal açıdan incelendiğinde gelecekte bir kurumun genel yönünü açıklayan bir süreç olarak ifade edilmektedir. Bunun yanında, stratejik planlama, gelecek yıllarda kurumun gerçekleştireceği ana eylemlerden söz ederek bir yol haritasının çizilmesidir. Örneğin, Avrupa Birliği bünyesindeki kurumların stratejik planlamadaki ana yaklaşımı, Avrupa Birliği Komisyonu kararlarının yıllık politika stratejisi temelinde ve kurumsal anlamda koordinasyonunun sağlanmasıdır (Matei ve Dogaru, 2012: 5). 
Kamu politikalarının etkinliği için koordinasyon ve koordinasyona bağlı kurumlar arası işbirliği faaliyetleri önemli yer tutmaktadır. Aynı şekilde, stratejik planlama ile ilgili süreçlerde, kamu kurumları ve planlama kapsamındaki grupların dâhil olduğu bir süreç olması yanında, kamu politikalarının önceliklerinin ve hedeflerinin belirlenmesine katkı sağlamaktadır (Matei ve Dogaru, 2012: 4). Kamu politikası sürecinde stratejik planlama, politika önceliklerini, hedeflerini ve anlayışını ortaya çıkardığından dolayı doğrudan katkı sağlamaktadır. Merkezi yönetim birimlerinin kamu politikalarının belirlenmesinde planlama, koordinasyon ve işbirliği önemli olduğundan söz konusu birimlerin stratejik planlarının belirlenmesinde de yine bu safhaların kayda değer bir yeri bulunmaktadır. Buna ek olarak, stratejik planlama uygulamaları, bakanlık ve ilgili kamu kurum ve kuruluşlarında ulusal ve sektörel politikalarla koordineli ve etkili bir kamu politikasının oluşturulmasında önemli rol oynamaktadır (TEPAV, 2012: 66).

\section{Türk Kamu Yönetiminde Stratejik Planlama ve Koordinasyon Üzerine Değerlendirmeler}

Türk kamu yönetiminde stratejik planlamanın yasal alt yapısı, 1 Ocak 2006 tarihinde yürürlüğe giren 5018 sayılı Kamu Mali Yönetim ve Kontrol Kanunu (KMYKK) ile gerçekleştirilmiştir. Bu kanun ile birlikte, Türk kamu yönetimlerinde strateji geliştirme birimleri oluşturulmuştur. Bu birimler, 2006 yılında yayımlanan "Strateji Geliştirme Birimlerinin Çalışma Usul ve Esasları Hakkında Yönetmelik” ile stratejik planlama çalışmalarının koordinasyonu ile görevli kılınmıştır. Genel olarak, Türk kamu yönetiminde merkezi koordinasyondan sorumlu iki bakanlık bulunmaktadır. Bunlardan birincisi, stratejik planların düzenlemesi ve koordinasyonun sağlanması görevini yürüten Kalkınma Bakanlığı'dır. ${ }^{1}$ İkincisi, stratejik planlarda var olan performans esaslı bütçelemenin ve performans programlarının düzenlemesi ve koordinasyonun sağlanması görevini yürüten Maliye Bakanlığı’dır (KMYKK, 2003: m.1). 5018 sayılı Kanun, koordinasyonun sağlanması ile ilgili olarak Maliye Bakanlı̆̆ı’na bazı yetkiler vermiştir. $\mathrm{Bu}$ bağlamda, Maliye Bakanlığı bünyesinde kamu idarelerinin iç denetim sistemlerinin izlemesi, koordinasyon ve işbirliğinin sağlaması üzere bağımsız ve tarafsız bir birim olarak görev yapmak için İç Denetim Koordinasyon Kurulu kurulmuştur.

Merkezi koordinasyon kurullarına örnek teşkil edecek bazı birimler bulunmaktadır. Bunlar, Maliye Bakanlığı bünyesindeki Mali Suçlarla Mücadele Koordinasyon Kurulu, Başbakanlık Hazine Müsteşarlığı bünyesindeki Ekonomi Koordinasyon Kurulu, İçişleri Bakanlığı bünyesindeki Kaçakçılık İstihbarat Koordinasyon Kurulu, Enerji ve Tabii Kaynaklar Bakanlığı bünyesindeki Enerji Verimliliği Koordinasyon Kurulu’dur.

Yerel yönetim birimlerinde koordinasyonun sağlanmasına örnek teşkil edecek birimlerde bulunmaktadır. Valilikler bünyesindeki İl Planlama ve Koordinasyon Müdürlükleri bu birimlere örnek gösterilebilir. Söz konusu birimin görevleri; valiliğin yetkili olduğu mülki alanda, il

1 Koordinasyonun sağlanması ile ilgili olarak, 5018 sayılı Kanun ile kurulan Strateji Geliştirme Başkanlığı bünyesinde, Stratejik Plan Çalışma ve Koordinasyon Grubu oluşturulmuştur. Stratejik Plan Çalışma ve Koordinasyon Grubu’nun amacı, stratejik planların hazırlanmasında koordinasyonun sağlanması görevini yürütmektir. 
düzeyindeki planlamanın, programlamanın, koordinasyonun ve izlemenin sağlanmasıdır. Bunun yanı sıra, yerel yönetimlerin yeniden yapılanmasına yönelik 2012 yılında yürürlüğe giren 6360 sayılı Kanun'da koordinasyonun sağlanması ile ilgili yenilikler getirilmiştir. Buna göre, büyükşehirlerde kapatılan il özel idarelerinin yerine valilikler bünyesinde yatırımın izlenmesi ve koordinasyonun sağlanmasında görevli, Yatırımı İzleme ve Koordinasyon Başkanlıkları kurulmuştur (Gündoğdu, 2015: 133).

Türk kamu yönetiminde stratejik planlama ve koordinasyonun sağlanması sürecinde bazı gelişmeler yaşanmıştır. Bu gelişmeler, Onuncu Kalkınma Planı (2014-2018) hazırlık çalışmaları doğrultusunda Kalkınma Bakanlığı tarafından oluşturulan "Kamuda Stratejik Yönetim Çalş̧ma Grubu”nun hazırladığı raporda şu şekilde özetlenmiştir (Kalkınma Bakanlı̆̆ı, 2013a):

> Kamu idarelerinde stratejik planlama ve koordinasyona yönelik süreçler giderek kurumsal kültürünün bir parçası haline gelmeye başlamaktadır.

$>$ Kamu idarelerinin çoğu, stratejik planlama ve koordinasyonun sağlanması sürecini öğretici görmektedirler. $\mathrm{Bu}$ durum, kamu idarelerinin kurumsal gelişimlerini olumlu yönde etkilemektedir.

> Katılımclık, şeffaflık, hesap verebilirlik, sonuç ve performans odaklılık gibi kavramlar stratejik yönetim süreciyle birlikte Türk kamu yönetiminde bakış açısı farklılı̆̆ı kazandırmıştır. Kamu idarelerinde bu kavramların kullanılması giderek yaygınlaşmaya başlamıştır.

Türk kamu yönetiminde stratejik planlama ve koordinasyon ile ilgili bu gelişmeler yaşanmasına rağmen uygulamada bir takım eksiklikler bulunmaktadır. Bu konuda özellikle, Avrupa Birliğinin "2015 yılı İlerleme Raporu" ve Kalkınma Bakanlığı̉nın hazırlamış olduğu "Stratejik Yönetimde Kapasite Geliştirme Teknik Destek Projesi Revize Edilmiş Taslak Boşluk Değerlendirme Raporu" Türk kamu yönetiminde stratejik planlama ve koordinasyon eksikliği ile ilgili değerlendirmeleri kapsamaktadır.

Kalkınma Bakanlığı’nca hazırlanan Rapora dayanarak, stratejik planlama ve koordinasyon eksikliği ile ilgili aşağıdaki tespitler yapılmaktadır (Kalkınma Bakanlığı, 2013b):

> Stratejik yönetimde merkezi koordinasyon sorumluluğu olan kurumlar (Bakanlıklar gibi) koordinasyon ve rehberlik sorumluluklarını yalnızca şeklen yürütmektedirler.

> Türk kamu yönetiminde kamu kurumlarının üst düzey planlama belgeleri (Ulusal Kalkınma Planı, bölgesel kalkınma planları gibi) ile kendi stratejik planları arasında farklılıklar bulunmaktadır. Bu durum, kamu kurumlarının amaç ve kapsam açısından çarpık bir görüntü oluşturmalarına yol açmaktadır.

$>$ Türk kamu yönetiminde kurumların tanıdığı ve sisteme öncülük etme kapasitesine sahip olan, genel ve merkezi bir koordinasyon yapısının bulunmaması stratejik planlama ile kamu kurumları ve yönetim süreçleri arasında ilişkiyi olumsuz etkilemektedir. 
$>$ Türk kamu yönetiminde stratejik planlama, henüz kamu kurumlarının faaliyetlerini düzenleyememektedir. Uygulamada stratejik planların, etkin bir şekilde kullanılması yerine genel itibariyle 'rafta' bekletilmektedir.

> Türk kamu yönetimindeki bakanlıkların, planlamış oldukları gelecek stratejik planlama süreci ile ilgili olarak Strateji Geliştirme Başkanlığı ve diğer daireler arasındaki iç iletişim; diğer dairelerle olan istişare eksiklikleri ve koordinasyon konusunda eksiklikler bulunmaktadır. Bu mevcut durum, Türk kamu yönetimi kültüründe düşük kurumsal kapasite sorunu oluşturmaktadır.

> Bazı koordine edici merkezi kuruluşların (Kalkınma Bakanlığı, İçişleri Bakanlı̆̆ı, Yükseköğretim Kurulu gibi) gözetim sorumluluğu bulunmaktadır. Ancak, etkin bir koordinasyon veya değerlendirme işlevi dikkate alındığında hesap verme sorumlulukları sinırlidir.

Avrupa Birliği Komisyonu’nun, Türkiye’nin ilerlemesi ile ilgili yayınladığı 2015 yılı ilerleme raporunda, koordinasyon eksikliği ile ilgili şu tespitler yapılmaktadır (Avrupa Birliği Komisyonu, 2015):

> Politika geliştirme ve koordinasyon ile ilgili olarak; merkezi hükümet birimleri arasında politika koordinasyonunun genel anlamda yeterli olduğu, ancak koordineli bir yıllık planlama ve hükümetin tümünün performansının izlendiği bir sistemin bulunmadığı ifade edilmektedir.

> Çalışma ve Sosyal Güvenlik Bakanlığı’na bağlı olan Devlet Personel Başkanlığı, insan kaynaklarının yönetilmesinde merkezi koordinasyon sorumluluğuna sahip olmasına karşın modern insan kaynakları yönetimi standartlarının sistemli bir şekilde uygulanmasını temin edecek koordinasyon ve izleme kapasitesinden eksiktir. Bu durum, kamu hizmetlerinin etkin bir biçimde yönetilmesine engel oluşturmaktadır.

> İdarenin güçlendirilmesinden sorumlu Başbakanlık İdareyi Geliştirme Başkanlığı’nın yeterli koordinasyon yetkisine ve kapasitesine sahip olmayışı, planlama belgelerinin izlenmesi ve rapor edilmesi için ortak bir sistemin geliştirilememesine neden olmuştur.

> Türk kamu yönetiminde kamu-özel ortaklıklarının sayılarının giderek artmasına karşın, uygulamada bu ortaklıkların koordinasyonundan, denetiminden ve izlenmesinden sorumlu birim bulunmamaktadır.

$>$ Kalkınma Bakanlığı, kurumsal çerçeveye ilişkin koordinasyon görevini yürütürken sınırlı düzeyde sorumluluk almaktadır.

Bununla birlikte, Avrupa Birliği, Türkiye’nin ilerlemesi ile ilgili en son yayınladığı 2016 raporunda, koordinasyon eksikliğiyle ilgili tespitler yapmıştır. Bu bağlamda, söz konusu Raporun kamu yönetimi reformu başlığı altında, 2015 yılında tavsiye edilen kapsamlı bir reform stratejisi ve reformist uygulamaların halen hayata geçirilemediği belirtilmiştir. Bu rapor, genel anlamda değerlendirildiğinde, 2015 yılı ilerleme raporunda ifade edilen koordinasyon eksikliği ile ilgili maddelerin tekrar edildiği ortaya çıkmaktadır (European Commission, 2016). 
Türk kamu yönetiminde sözü edilen bu eksiklikler, uygulamadaki boşlukların neler olduğunu göstermektedir. Bu bağlamda, koordinasyon etkinliğinin değerlendirilmesi ve yapılması gereken iyileştirmeler şu şekilde özetlenebilir:

$>$ Türk kamu yönetiminde genel anlamda koordinasyonun, özelde ise stratejik planlarda koordinasyonun sağlanması amacıyla işbirliği, etkinlik, etkililik, şeffaflık, hesap verebilirlik ilkeleri ve yönetişim süreçlerinin daha fazla ön planda tutulması gerekir. Bu bağlamda, genel bir reform stratejisi veya eylem planının belirlenip hayata geçirilebilir.

> Türk kamu yönetiminde, 2003 yılında temeli atılan adımlar çerçevesinde oluşturulan "Kamu Yönetimi Temel Kanunu”nun amacında var olan, katılımc1, şeffaf, hesap verebilir bir yönetim anlayışı ile kamu hizmetlerinin kaliteli, etkili ve verimli bir biçimde yerine getirilmesi amacıyla kamu yönetimi reformunun etkin koordinasyonu yeniden düzenlenebilir.

> Stratejik planlamada koordinasyon etkinliğinin sağlanması yönünden, kurumsal yapılanmada hiyerarşik temelli geleneksel dikey yapılanmadan ziyade yönetişim süreçlerinin etkili olduğu yatay ve esnek yapılanma gerekebilir. Kamu yönetiminde etkinliği sağlamak amacıyla kurumsal yapılanma anlamında küçülme, ancak etkinlik anlamında büyüme önem taşımaktadır.

> Türk kamu yönetiminde koordinasyon eksikliğinin çözümü amacıyla, genel bir yol haritasının oluşturulması, koordinasyon çözümü için kurumlar arası çalışma gruplarının veya ilgili yönetim mekanizmalarının geliştirilmesi gereklidir.

$>$ Stratejik planların koordinasyon temelinde etkinliği ve program geliştirme ve yönetimi için Türk kamu yönetiminde performansa dayalı bir sisteme geçilebilmesi ve bu bağlamda, destekler-teşviklerin kullanılması düşünülebilir (Kalkınma Bakanlığı, 2013b).

> Strateji Geliştirme Birimlerỉnin uygulamada finansman daireleri gibi görünmelerinden ziyade; aslına uygun bir biçimde kurumlarda koordinasyondan sorumlu stratejik yönetimin işleyişine katkı sağlayan bir birime dönüştürülmesi önem arz etmektedir (Kalkınma Bakanlığg1, 2013b).

5018 sayılı Kanunla yürürlüğe giren stratejik yönetim modelinin amaçlarına uygun olarak; stratejik planlarda ve koordinasyonda kurumsal kapasitenin artırılması ve farkındalığın oluşturulması amacıyla kamu personeli ile işbirliği içinde pilot kurumlara eğitim programları verilebilir (Kalkınma Bakanlığı, 2013b).

\section{Değerlendirme}

Ulusal hükümetlerin daha iyi koordinasyon ve strateji geliştirmelerine yardımcı olacağı öngörülen ve küreselleşmeye bağlı gelişen küresel yönetişim yapıları, karşılıklı işbirliğini öne çıkarmaktadır. Yerelden küresele doğru artan işbirliği ve koordinasyon, kamu yönetimlerini de etkilemiştir. Bu bağlamda, işbirliği ve koordinasyon temelinde kamu yönetiminde etkinliğin sağlanabilmesi ve stratejik yönetim anlayışına bağlı olarak stratejik planlar hazırlanmaktadır. 
Türk kamu yönetiminde merkezi düzeyde kamu politikalarının geliştirilmesi, bakanlıklar ve diğer kamu kurum ve kuruluşlarında koordinasyon ve stratejik planlama kullanımının zorunlu hale getirilmesi 5018 sayılı Kanun ile gerçekleşmiştir. Türk kamu yönetiminde stratejik planların zorunlu hale getirilmesi sonucu uygulamada ortaya çıan ulusal eylem planları, kalkınma planları ve kamu kurumlarındaki sektörel planların üst ve alt belge olarak uyuşmaması ve koordinasyon eksikliği, kamu yönetiminin etkinliğini azaltmaktadır. Bu nedenle, Türk kamu yönetiminde koordinasyon ve stratejik planlama ile ilgili sıralanan eksiklikleri gidermek ve kamu kurumlarında stratejik planlama sürecinde paydaşların da dahil olduğu stratejik planların geliştirilmesi için belli bir yaklaşım gerekmektedir.

Bu yaklaşımın oluşması sonucunda; kamu kurumlarında var olan stratejik planların uygulamada etkin, anlaşılır ve yol gösterici olması; kaynak kullanımında etkinliğinin sağlanması, şeffaflık ve hesap verebilirlik ilkelerinin hayata geçirilebilmesi beklenmektedir. Ayrıca, Türk kamu yönetiminde kurumlar arası istişare ve işbirliği mekanizmalarının oluşturulması, iletişim kanallarının güçlendirilmesi ve kamu politikaları değişikliklerinde ilgili tüm paydaşların görüş ve gözlemlerinin ön plana alındığı kapsayıcı bir anlayışın yönetim kültüründe oluşturulması gerekmektedir. Bundan başka, koordinasyon, işbirliği ve stratejik planların etkinliği açısından başka ulus veya ulus üstü örneklerin Türk kamu yönetimi kültürü içerisinde içselleştirilerek kullanılması, uygulamanın işlevselliğini arttırabilmektedir. Son olarak, kamu politikalarında koordinasyon ve tutarlılığın sağlanması amacıyla yönetimin tek taraflı kararlar alması yerine, diğer kurumlarla işbirliği yapma zorunluluğu açıktır. 


\section{Kaynakça}

Avrupa Komisyonu (2015), Türkiye İlerleme Raporu 2015, SWD (2015) 216, 10.11.2015, Brüksel.

Boughton M. James ve Colin I. Bradford (2007), "Global Governance: New Players, New Rules: Why the 20th-century model needs a makeover”, Finance \& Development, 44(4), (December): 10-14.

Bryson, John M. (2004), Strategic Planning for Public and Nonprofit Organizations, 3. Edition, San Francisco: Jossey-Bass A Wiley Imprint.

European Commission (2016), “Commission Staff Working Document- Turkey 2016 Report” SWD (2016) 366, 9.11.2016, Brussels, http://ec.europa.eu/enlargement/pdf/key_documents/2016/20161109_ report_turkey.pdf, (Erişim Tarihi: 14.11.2016).

Gregory, Robert (2003), “All the King's Horses and All the King's Men: Putting New Zealand's Public Sector Back Together Again”, International Public Management Review, 4 (2): 41-58.

Gündoğdu, Hakan G. (2015), “6360 Sayılı Büyükşehir Yasası ve Kamu Personelinin Durumu”, Afyon Kocatepe Üniversitesi İİF Dergisi, 2 (Aralık): 127-138, DOI No: 10.5578/jeas.10183.

Heywood, Andrew (2014), Küresel Siyaset, (Çev.) Nasuh Uslu ve Haluk Özdemir, 3. Baskı, Ankara: Adres Yayınları.

Kalkınma Bakanlığı (2013a), “Kamuda Stratejik Yönetim Çalısma GrubuRaporu”,http://www.sp.gov.tr/ upload/xSpKutuphane/files/jYEng+Kamu da_Stratejik_Yonetim_Calisma_Grubu_Raporu.pdf, (Erişim Tarihi: 24.10.2016).

Kalkınma Bakanlığı (2013b), Stratejik Yönetimde Kapasite Geliştirme Teknik Destek Projesi: "Stratejik Yönetimde Kapasite Geliştirme Teknik Destek Projesi Revize Edilmiş Taslak Boşluk Değerlendirme Raporu”, ～www.sp.gov.tr/upload/Sayfa/54/files/Bosluk_Degerlendirme_Raporu_-_GAR.docx, (Erişim Tarihi: 04.10.2016).

Kavruk, Hikmet (2005), “Yerel Yönetim Reformu ve Yönetişim Öngörüsü”, 21. Yüzyılda Türkiye’de Sosyal Bilimler ve Toplum Sorunları Sempozyumu Bildiriler Kitabı İçinde, (Ed.) Levent Özmen ve M. Akif Sözer, Ankara, 362-377.

Latif, Dilek (1999), "United Nations Changing Role in the Post-Cold War era", Turkish Yearbook V. XXX, 2366.

Malone, Thomas W. (1988), “What is Coordination Theory?”, (Working Paper: 2051-88), Cambridge: Massachusetts, Massachusetts Institute of Technology Sloan School of Management, 1-29.

Malone, Thomas W. ve Crawston, Kevin (1994), “The İnterdisciplinary Study of Coordination”, in ACM Computing Surveys, 26 (1): 87-119.

Matei, Ani ve Dogaru, Tatiana-Camelia (2012), “Coordination of Public Policies through Strategic Planning Instruments: Romania Case study”, MPRA Paper No. 53674, https://mpra.ub.uni-muenchen. de/53674/1/MPRA_paper_53674.pdf, (Erişim Tarihi: 1.10.2016).

Metcalfe, Les (1994), "International Policy Co-ordination and Public Management Reform”, in International Review of Administrative Sciences, London, Thousand Oaks and New Delhi: Sage, Vol. 60: 271-290.

OECD, (1996), Globalisation: What challenges and opportunities for governments?, Paris: OECD.

OECD, (2003), Public Sector Transparency and the International Investor, Paris: OECD.

Okçu, Murat (2005), “Avrupa Yönetsel Alanına Doğru Türk Kamu Yönetimi: Çok Düzlemli Yönetişim”, http://www.tepav.org.tr/upload/files/1269868421r8525.Avrupa_Yonetsel_Alanina_Dogru_Turk_ Kamu_Yonetimi_Cok_Duzlemli_Yonetisim.pdf, (Erişim Tarihi: 14.09.2016).

Pollitt, Christopher, Xavier Girre, Jeremy Lonsdale, Robert Mul, Hilkka Summa ve Marit Waerness (1999), Performance or Compliance? Performance Audit and Public Management in Five Countries, Oxford: Oxford University Press. 
Pollitt, Christopher ve Geert Bouckaert (2004), Public Management Reform: A Comparative Analysis, 2. Edition, Oxford: Oxford University Press.

State Services Commission (2008), "Factors for Successful Coordination - A Framework to Help State Agencies Coordinate Effectively”, New Zealand, Wellington, https://www.ssc.govt.nz/sites/all/files/ Factors-publication_0.pdf, (Erişim Tarihi: 24.10.2016).

Steiss, Alan Walter (2003), Strategic Management for Public and Nonprofit Organizations, New York: Marcel Dekker Inc.

Sumpor, Marijana (2006), "Creating Collaborative Advantages Through Coordination of Regional Development Activities”, https://www.econstor.eu/handle/10419/118291, (Erişim Tarihi: 24.10.2016).

TEPAV (2012), “KKTC Politika Oluşturma ve Koordinasyon Sistemi’nin Fonksiyonel ve Kurumsal Analizi”, http://www.tepav.org.tr/upload/files/14550069721.KKTC_Politika_Olusturma_ve_Koordinasyon_ Sistemi_nin_Fonksiyonel_ve_Kurumsal_Analizi.pdf, (Erişim Tarihi: 14.06.2016).

Weiss, Thomas G. (2013), Global Governance: Why? What? Whither?, New York: John Wiley\&Sons.

Volz, Ulrich (2011), Regional Integration, Economic Development and Global Governance, Cheltenham, UK ve Northampton: Edward Elgar Publishing.

Yılmaz, Kutluhan (2003), “Kamu Kuruluşları İçin Stratejik Planlama Uygulaması”, Sayıştay Dergisi, (50-51): 67-86.

5018 sayılı Kamu Mali Yönetimi ve Kontrol Kanunu (24.12.2003 tarih ve 25236 sayıll, Resmi Gazete).

5436 sayılı Kamu Mali Yönetimi ve Kontrol Kanunu ile Bazı Kanun ve Kanun Hükmünde Kararnamelerde Değişiklik Yapılması Hakkında Kanun (24.12.2005 tarih ve 26033 sayılı, Resmi Gazete). 
